\title{
Effectiveness of direct oral anticoagulants with initial intensive therapy for a giant thrombus swivelling in the right atrium
}

\author{
Shinichi Nakamura, Taku Rokutanda, Hirofumi Kurokawa, Yoshirou Onoue
}

Cardiovascular Medicine, Hitoyoshi Medical Center, Hitoyoshi, Kumamoto, Japan

\section{Correspondence to} Dr Shinichi Nakamura; nakamurascardio@gmail.com

Accepted 2 November 2019

\section{DESCRIPTION}

Case 1. A 45-year-old man with dyspnoea. In his echocardiography, we detected a $35 \times 15 \mathrm{~mm}$ left ventricular thrombus (LVT) with a low ejection fraction. Conventional therapy (unfractionated heparin combined with vitamin $\mathrm{K}$ antagonists) for the LVT resulted in an acute inferior myocardial infarction due to an embolisation of the LVT. Case 2. A 35-year-old man with dyspnoea. In his echocardiography, we detected a left ventricular/left atrial/right ventricular thrombus with a low ejection fraction. Conventional therapy resulted in a cerebral infarction, renal infarction, splenic infarction

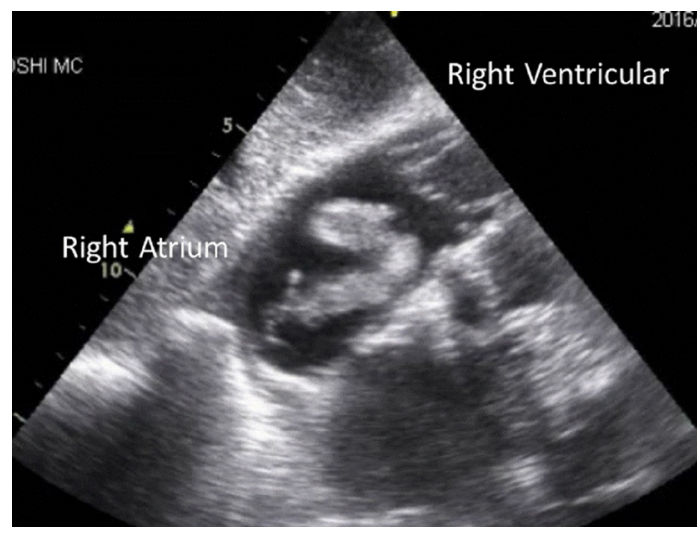

Figure 1 The giant thrombus in the right atrium.

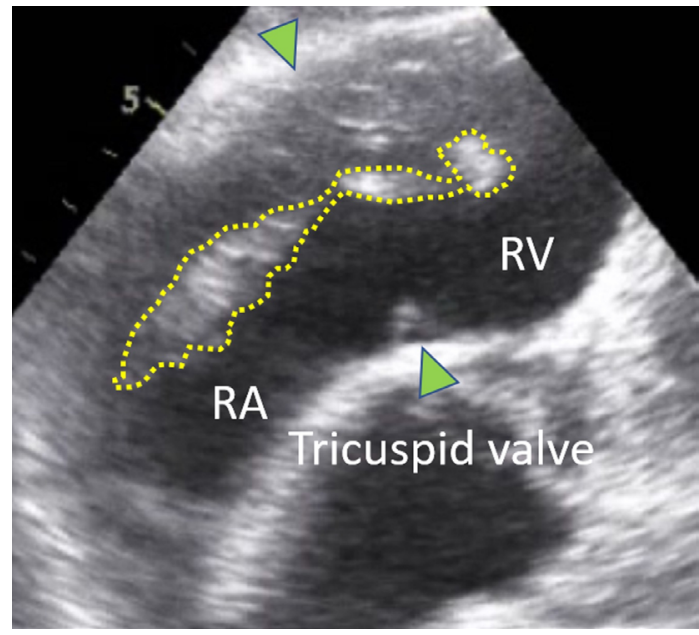

Figure 2 The giant thrombus in the right atrium (RA) temporarily enters into the right ventricular (RV), but since it is cord-like, it returns immediately back into the RA.

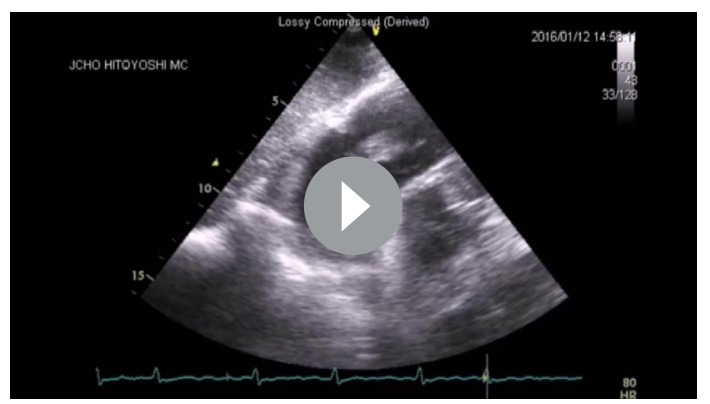

Video 1 Transthoracic echocardiography (TTE) showing the giant thrombus in the right atrium (RA). $10 \times 80 \mathrm{~mm}$ cord-like structure that was swivelling like a water wheel in the RA from the tricuspid regurgitation-jet.

and pulmonary thromboembolism (PTE). Problems of conventional therapy: (1) Warfarin takes time to reach a therapeutic range and needs frequent activated partial thromboplastin time (aPTT) measurements. (2) Since warfarin deactivates protein $\mathrm{C}$ and protein $\mathrm{S}$, two endogenous anticoagulants, the initiation of warfarin leads to a transient hypercoagulable state. ${ }^{1}(3)$ Therefore, pre-administration with heparin is required. (4) However, according to the JAVA study, the level of anticoagulation is subtherapeutic in approximately $40 \%$ of cases. ${ }^{2}$

Case 3. An 89-year-old man with syncope. In his echocardiography, we detected a $10 \times 80 \mathrm{~mm}$ cordlike structure that was swivelling in the right atrium (RA) due to tricuspid regurgitation (figures 1 and 2 and video 1 ). In the lower extremity vein echo, there was a deep vein thrombosis (DVT) beyond the

Learning points

- Conventional therapy (unfractionated heparin combined with a vitamin $\mathrm{K}$ antagonist (VKA)) for a giant thrombus in the right atrium (RA) may cause cardiogenic shock due to showeremboli and we selected to use a direct oral anticoagulant (DOAC) with the initial intensive therapy.

- Although the patient had chronic kidney disease (CCR 32.4), we chose an initial intensive therapy with rivaroxaban.

- It was thought that by using DOACs with a rapid onset of the effect, even if the RA thrombus were to migrate to the pulmonary artery, it would shrink rapidly there and would not cause cardiogenic shock. 
right femoral vein. The D-dimer was 62.6 , and it seemed that the DVT had become liberated and dropped into the RA. Conventional therapy for a giant thrombus in the RA may cause cardiogenic shock due to shower-emboli and we selected to use direct oral anticoagulants (DOACs) with the initial intensive therapy.

Due to the 2-day administration of oral rivaroxaban $15 \mathrm{mg}$ two times per day, the D-dimer decreased from 62.6 to 17.1 , and in the echocardiography, the RA thrombus also disappeared. He had chronic kidney disease with a creatinine clearance (CCR) of 32.4, but no haemorrhagic complications were observed.

A PTE with cardiogenic shock has a poorer prognosis than an acute myocardial infarction and the treatment for an RA giant thrombus is very risky. It was thought that by using DOACs with a rapid onset of the effect, even if the RA thrombus were to migrate to the pulmonary artery, it would shrink rapidly there and would not cause cardiogenic shock.
Contributors SN has contributed to planning, conduct, reporting, conception and design. SN wrote the initial draft of the manuscript. TR has contributed to analysis and interpretation of data. HK and YO have contributed to data collection and interpretation. All authors approved the final version of the manuscript and agreed to be accountable for all aspects of the work in ensuring that questions related to the accuracy or integrity of any part of the work are appropriately investigated and resolved.

Funding The authors have not declared a specific grant for this research from any funding agency in the public, commercial or not-for-profit sectors.

Competing interests None declared.

Patient consent for publication Obtained.

Provenance and peer review Not commissioned; externally peer reviewed.

\section{REFERENCES}

1 Azoulay L, Dell'Aniello S, Simon TA, et al. Initiation of warfarin in patients with atrial fibrillation: early effects on ischaemic strokes. Eur Heart J 2014;35:1881-7.

2 Nakamura M, Miyata T, Ozeki Y, et al. Current venous thromboembolism management and outcomes in Japan. Circ J 2014;78:708-17.

Copyright 2020 BMJ Publishing Group. All rights reserved. For permission to reuse any of this content visit

https://www.bmj.com/company/products-services/rights-and-licensing/permissions/

BMJ Case Report Fellows may re-use this article for personal use and teaching without any further permission.

Become a Fellow of BMJ Case Reports today and you can:

- Submit as many cases as you like

- Enjoy fast sympathetic peer review and rapid publication of accepted articles

- Access all the published articles

Re-use any of the published material for personal use and teaching without further permission

Customer Service

If you have any further queries about your subscription, please contact our customer services team on +44 (0) 2071111105 or via email at support@bmj.com.

Visit casereports.bmj.com for more articles like this and to become a Fellow 